Research Papers, part of a Special Feature on Aerial Insectivores

\title{
Identification of Putative Wintering Areas and Ecological Determinants of Population Dynamics of Common House-Martin (Delichon urbicum) and Common Swift (Apus apus) Breeding in Northern Italy Aires d'hivernage présumées et variables écologiques influençant la dynamique des populations nicheuses d'Hirondelle de fenêtre (Delichon urbicum) et de Martinet noir (Apus apus) du nord de l'Italie
}

\author{
$\underline{\text { Roberto Ambrosini }}^{1}$, Valerio Orioli $^{2}$, Dario Massimino $^{2}{ }^{\text {, and } \text { Luciano Bani }^{2}}$
}

\begin{abstract}
To identify the causes of population decline in migratory birds, researchers must determine the relative influence of environmental changes on population dynamics while the birds are on breeding grounds, wintering grounds, and en route between the two. This is problematic when the wintering areas of specific populations are unknown. Here, we first identified the putative wintering areas of Common House-Martin (Delichon urbicum) and Common Swift (Apus apus) populations breeding in northern Italy as those areas, within the wintering ranges of these species, where the winter Normalized Difference Vegetation Index (NDVI), which may affect winter survival, best predicted annual variation in population indices observed in the breeding grounds in 1992-2009. In these analyses, we controlled for the potentially confounding effects of rainfall in the breeding grounds during the previous year, which may affect reproductive success; the North Atlantic Oscillation Index (NAO), which may account for climatic conditions faced by birds during migration; and the linear and squared term of year, which account for nonlinear population trends. The areas thus identified ranged from Guinea to Nigeria for the Common House-Martin, and were located in southern Ghana for the Common Swift. We then regressed annual population indices on mean NDVI values in the putative wintering areas and on the other variables, and used Bayesian model averaging (BMA) and hierarchical partitioning (HP) of variance to assess their relative contribution to population dynamics. We re-ran all the analyses using NDVI values at different spatial scales, and consistently found that our population of Common House-Martin was primarily affected by spring rainfall (43\%-47.7\% explained variance) and NDVI (24\%-26.9\%), while the Common Swift population was primarily affected by the NDVI $(22.7 \%-34.8 \%)$. Although these results must be further validated, currently they are the only hypotheses about the wintering grounds of the Italian populations of these species, as no Common House-Martin and Common Swift ringed in Italy have been recovered in their wintering ranges.
\end{abstract}

RÉSUMÉ. Afin de cerner les causes de déclin des oiseaux migrateurs, les scientifiques doivent déterminer l'influence relative des changements environnementaux sur la dynamique des populations, tant sur les aires de reproduction et d'hivernage que sur les haltes migratoires. Cette démarche est particulièrement problématique lorsque les aires d'hivernage de populations spécifiques sont inconnues. Dans la présente étude, nous avons d'abord déterminé les aires d'hivernage présumées des populations d'Hirondelle de fenêtre (Delichon urbicum) et de Martinet noir (Apus apus) qui se reproduisent dans le nord de l'Italie; ces aires présumées correspondent aux endroits, dans l'ensemble de l'aire d'hivernage de ces espèces, où l'indice de végétation par différence normalisée (IVDN) - qui affecte peut-être la survie hivernale expliquait le mieux la variation annuelle des indices de population observés sur les aires de reproduction

\footnotetext{
${ }^{1}$ Department of Biotecnologies and Biosciences, University of MilanoBicocca, ${ }^{2}$ Department of Environmental and Landscape Sciences, University of Milano-Bicocca
}

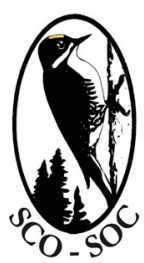

Sponsored by the Society of Canadian Ornithologists and Bird Studies Canada Parrainée par la Société des ornithologistes du Canada et Études d'oiseaux Canada

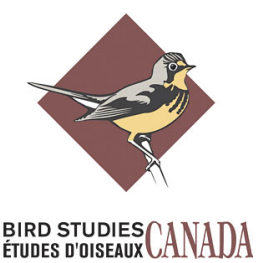


de 1992 à 2009. Au cours de ces analyses, nous avons aussi contrôlé les paramètres suivants : 1) les effets confondants possibles des précipitations s'étant produites sur les aires de reproduction durant l'année précédente, qui peuvent affecter le succès de reproduction; 2) l'indice d'oscillation nord-atlantique, qui est peut-être responsable des conditions climatiques rencontrées par les oiseaux durant leur migration; et 3) l'effet de l'année, linéaire ou au carré, qui est responsable des tendances de population non linéaires. Les aires ainsi déterminées s'étendaient de la Guinée au Nigeria pour l'Hirondelle de fenêtre et se situaient dans le sud du Ghana pour le Martinet noir. Nous avons ensuite procédé à la régression des indices annuels de population sur les valeurs moyennes d'IVDN des aires présumées d'hivernage et sur les autres variables, et avons utilisé le calcul de la moyenne des modèles bayésiens et la partition hiérarchique de la variance afin d'évaluer leur contribution relative à la dynamique des populations. Nous avons répété toutes les analyses avec des valeurs d'IVDN à différentes échelles spatiales, et avons invariablement constaté que notre population d'Hirondelle de fenêtre était surtout affectée par les précipitations printanières (variance expliquée de $43 \%$ à 47,7 \%) et l'IVDN (de $24 \%$ à 26,9\%), alors que notre population de Martinet noir était essentiellement affectée par l'IVDN (de 22,7 \% à 34,8 \%). Même si ces résultats doivent être validés davantage, ils représentent actuellement les seules hypothèses quant aux aires d'hivernage des populations italiennes, puisqu'aucune Hirondelle de fenêtre ou Martinet noir bagué en Italie n'a été encore retrouvé sur son aire d'hivernage.

Key Words: aerial insectivores; bird monitoring; Bayesian model averaging; hierarchical partitioning; ERA-Interim project; NAO; NDVI; Palearctic-African bird migration system

\section{INTRODUCTION}

Populations of aerial insectivore birds are declining both in the Palearctic and the Nearctic ecoregions (Sanderson et al. 2006, Nebel et al. 2010). Most of these species are migratory and their population dynamics are influenced by ecological processes occurring in their breeding and wintering areas, as well as along migration routes (Newton 2004, Calvert et al. 2009a). Several studies on migratory birds have pointed out that the ecological conditions they face during a period of their annual cycle may have carry-over effects on their performance in later stages. Indeed, it is known that conditions in the wintering grounds and en route affect winter and migration survival (Szép and Møller 2005, Stokke et al. 2005, Szép et al. 2006, Calvert et al. 2009a,b) and, therefore, the number of breeding pairs in the following year (Giralt and Valera 2007). As well, they influence the spring arrival date (Gordo et al. 2005, Gordo et al. 2007, Gordo and Sanz 2008, Balbotin et al. 2009), physiological condition of breeding individuals (Marra et al. 1998), and breeding performance in general (Saino et al. 2004, Smith and Moore 2005). By studying migratory birds in only one period and one area, ornithologists obviously introduce biases in their comprehension of the ecological determinants of variations in population size, which are primarily attributed to our general scant knowledge of the actual wintering grounds and migration routes of the vast majority of small-sized species. Indeed, in the PalearcticAfrotropical migration system, a single species, the Barn Swallow (Hirundo rustica), is widely studied, and yet the precise identification of wintering grounds of specific populations is still debated (however, see Ambrosini et al. 2009). Our fragmentary knowledge of the ecology and distribution of aerial insectivores, such as swifts and martins, during migration and in the wintering grounds, is likely a result of their strict aerial behavior, which limits the application of common field methods (e.g., ringing recoveries) to these species (Calvert et al. 2009a). Importantly, in the Eurasian-Afrotropical migration system, stable isotope distribution is poorly documented, thus currently precluding tracking the origin of migrants using the isotopic signature of, e.g., feathers (Webster et al. 2002, Szép et al. 2006, Hobson and Wassenaar 2008, Larson and Hobson 2009, Szép et al. 2009). The development of new technological devices may bridge this gap in our knowledge about the migration of small to medium sized birds in the near future (Stuchbury et al. 2009, Bachler et al. 2010). However, it is already possible to make some inferences about the ecological drivers of population dynamics of species whose wintering grounds and migration routes are poorly known by 
statistically modeling the probability of presence of birds from a breeding population in a putative wintering ground (Szép and Møller 2005, Szép et al. 2006).

The theoretical and methodological principles underlying this procedure were first proposed by Szép and Møller (2005) and Szép et al. (2006). Assuming that the survival rate of individuals of the population under scrutiny is mainly driven by conditions during wintering, they argued that potential wintering grounds of a population might be identified as those areas where year-to-year fluctuation in some general indices of environmental conditions correlate most strictly with year-to-year variation in population consistency observed at the breeding grounds. Despite the large degree of uncertainty in the results and the call for validation through independent methods (e.g., ring recoveries), the approach of Szép and Møller (2005) and Szép et al. (2006) is the only one applicable to species whose ecological characteristics have prevented the collection of large datasets of ring recoveries by common fields methods. As an index of environmental conditions, Szép and Møller (2005) and Szép et al. (2006) used the Normalized Difference Vegetation Index (NDVI), a general index of primary productivity that, in turn, determines secondary productivity in general and availability of flying insects in particular and, therefore, may affect winter mortality and population size of aerial insectivores (Saino et al. 2004, Szép et al. 2006, Giralt and Valera 2007, Balbontin et al. 2009). In addition, values for this index are readily available for wide regions of Africa. Year-to-year variations for this index in different African regions are related to year-to-year variation in the survival of ringed individuals of species whose strong breeding-site fidelity allows an easy application of capture-mark-recapture methods (Szép and Møller 2005, Szép et al. 2006). However, retrieving accurate estimates of survival rates for other species may not be as easy, or even practical, and in any case requires intensive field work. This has limited the application of their method to a few well-studied populations.

Here, we propose to implement the procedure proposed by Szép and Møller (2005) and Szép et al. (2006) to infer wintering grounds of populations based on a time series of indices of population size, such as those commonly obtained from extensive long-term bird monitoring schemes, so that information on the potential wintering grounds of a large number of populations can be quickly obtained from data already collected in the field. This information may be of importance for planning effective conservation strategies for declining species, although such results do need to be validated with independent evidence about the presence of birds from the population under scrutiny. However, to achieve this goal, it is necessary to simultaneously assess the relative importance of ecological conditions in the breeding and wintering grounds, in terms of population dynamics. Indeed, they are the result of the combined effects of birth rate, which depends primarily on conditions in the breeding grounds, and death rate, which is primarily affected by conditions during migration and wintering. Hence, it is necessary to model year-to-year variations in population indices not only according to NDVI data in different areas in the wintering grounds, but also according to environmental conditions in the breeding grounds.

This procedure is based on the underlying assumption that individuals breeding in a given area consistently move to the same wintering area in consecutive years, a condition known as "migratory connectivity" (Webster et al. 2002). Although the degree of migratory connectivity shown by migrant populations has rarely been quantified (however, see Ambrosini et al. 2009), several other ornithological studies have also assumed that migrant bird populations consistently return every year to the same wintering areas, at least at a coarse geographical scale (Saino et al. 2004, Gordo et al. 2005, Szép and Møller 2005, Szép et al. 2006, Robinson et al. 2008).

We used this approach to identify putative wintering areas of the populations of two aerial insectivore and long-distance migrant birds, namely the Common House-Martin (Delichon urbicum) and the Common Swift (Apus apus) breeding in northern Italy, and to assess the relative importance of ecological conditions in the breeding and wintering grounds for their population dynamics. We note that this is currently the only approach that may allow for the identification of putative wintering areas for these species, since no Common House-Martin or Common Swift ringed in Italy has ever been recovered in Africa (Spina and Volponi 2008a,b), and there is little recapture data for both species, even at continental scale (Zink 1975, Wernham et al. 2002). 
Data on the annual population sizes of these species were obtained from an extensive monitoring program of breeding birds performed in a wide area in northern Italy in 1992-2009. These data were related to: (1) the NDVI in different areas of Africa within the wintering ranges of these species, (2) the total amount of rainfall in the study area during March-April of the year preceding each survey, and (3) the winter North Atlantic Oscillation (NAOw) index. The linear and the squared terms of year were also included in all the analyses to account for temporal trends in population indices not explained by the other variables.

The wintering range of the Common House-Martin was identified as the whole of Africa south of latitude $20^{\circ} \mathrm{N}$ (Turner 2004). A large degree of uncertainty characterizes the identification of the wintering range of the Common Swift. Chantler (1999) has indicated that it is comprised of the part of Africa south of the equator, excluding the Cape Province, whereas Moreau (1972), Cramp (1985), and Cramp et al. (2004) have suggested that the wintering range of this species may extend northward to about $12^{\circ} \mathrm{N}$. Conservatively, we used the same area south to $20^{\circ} \mathrm{N}$ as the wintering range of both species, within which we aimed to identify the putative wintering areas of our populations.

Hirundines (Hirundinidae) seem to be sensitive to variations in rainfall both during the breeding and the wintering season, as rain affects the availability of flying insects (Wolda 1978, Frampton et al. 2000), and the same may be true for other aerial insectivores such as swifts. However, rainfall in the breeding grounds during the breeding season does not seem to affect the adult mortality of aerial insectivores (Robinson et al. 2008), which is usually low $(<5 \%)$ in this period (Marra and Holmes 2001, Sillett and Holmes 2002). Conversely, rainfall in late winter and early spring in the breeding grounds may affect the availability of flying insects not only for adult sustenance, but also for nestling rearing and, therefore, it can influence reproductive success and consequently the population size of the following year. For this reason, we related population indices of a given breeding season with rainfall of the preceding year. Variation in rainfall in Africa is accounted for by the NDVI, which is also a direct estimate of primary productivity. Therefore, we did not include any direct measure of rainfall in the wintering grounds in the analyses.
We did not include variables accounting for meteorological or ecological conditions in precise areas along the migration route, given the lack of detailed knowledge about the migration routes and timing of these species. Conversely, we used the NAOw index, which is a general index of climatic conditions across Europe and the Mediterranean region, to account for ecological conditions faced by migrants en route and at the beginning of the reproductive season (Stenseth et al. 2002).

Several other ecological, climatic, and environmental indices can be entered in the models as predictors, but we preferred to rely on indicators of general ecological conditions, such as the NDVI, rainfall, and the NAOw index, given our ignorance about the ecological determinants of the distribution of these common aerial feeders, and to minimize the number of predictors entered in regression models based on a rather short time series of data.

\section{METHODS}

\section{Study Area and Field Methods}

Lombardy is a large $\left(23,861 \mathrm{~km}^{2}\right)$ region in northern Italy with lowlands (47\%), hills (13\%), and mountains $(40 \%)$. Predominant land uses are: agriculture $(40.0 \%)$, forest $(25.4 \%)$, and urban and residential areas $(12.6 \%)$. Lowlands, which are the most suitable foraging habitats for breeding populations of the Common House-Martin and the Common Swift in Lombardy, are intensively cultivated, maize fields being the prevalent land use. Although both species primarily breed in urbanized areas, they can move far away to reach feeding grounds, mainly comprised of agricultural areas (Cramp 1985, 1988).

Annual population indices of both the Common House-Martin and Common Swift were assessed using a database of 387-1503 annual point counts performed in 1992, 1995, 1996, and 1998-2009 (see Bani et al. 2009 for full details on sampling methods). Ten-minute point counts at unlimited distances were performed by a homogeneous census team, from sunrise to 11:00 AM in good weather conditions (sunny to cloudy, with no rain nor strong wind) during the main breeding season (10 May-20 June) (Blondel et al. 1981, Fornasari et al. 1998). Most point counts were performed according to a long-term monitoring project of breeding bird 
populations in Lombardy. However, all data for years 1998-1999 and 3\%-59\% of data for years 2000-2004 were collected according to different sampling schemes (see Bani et al. 2009). Estimates of annual population abundance obtained directly from the data recorded in each year may, therefore, be biased, as the same species may occur at different densities in different geographical areas of Lombardy. For example, if, in a given year, forests were sampled more intensively than in other years, population abundances in that year would be biased toward forest species. To obtain an unbiased annual population index for each species, we first regressed the observed abundances on several environmental variables that affect the distribution of the species under scrutiny (see Bani et al. 2009 for details), so as to obtain the expected number of individuals at each point count in each year. The annual population index and its standard error were estimated as the bootstrap (1000 resamples) mean and standard error of the ratios between the number of individuals observed at each point count and that expected from the model (see Massimino et al. 2008 for full details on the calculation of the population index). The models from which the index is calculated are unaffected by the sampling bias, as they are based on a very large sample (13,176 point counts). Conversely, annual population abundances obtained from the data without a modeling approach are biased, as in some years a relevant fraction of, or even all, point counts may have been collected according to biased sampling schemes. Annual population indices and their standard errors are shown in Fig. 1.

\section{Environmental Data}

The NDVI is a measure of primary productivity on land surface, and its magnitude is related to the photosynthetic activity of vegetation. Normalized Difference Vegetation Index data are collected by the National Oceanic and Atmospheric Administration (NOAA) satellites and are available for the whole of Africa with an $8 \times 8 \mathrm{~km}$ spatial resolution and 10day time intervals (Tucker et al. 2005) at the Famin e Early Warning Systems Network (FEWS NET) website in WinDisp format. Pixels with values of 1.012 (missing values), 1.016 (masked pixels), and 1.020 (water pixels) were excluded from the analyses as suggested by the FEWS NET website, and mean NDVI values from December to February, i.e., the bulk of the wintering season for our species, in cells of $0.5^{\circ}$ latitude $\mathrm{x} 0.5^{\circ}$ longitude were calculated and related to population indices in the following breeding season.

A major issue in this analysis is the choice of the proper size of the cells for the calculation of the mean NDVI value. An omnidirectional variogram on NDVI values in $0.5^{\circ} \times 0.5^{\circ}$ cells indicated that strong spatial autocorrelation occurred in NDVI data up to a spatial scale (range of the variogram) of $30^{\circ}$ of latitude or longitude, which was clearly too coarse for identifying the putative wintering areas of migrant birds. Therefore, we calculated mean NDVI values at different spatial scales, by aggregating spatially contiguous $0.5^{\circ} \times 0.5^{\circ}$ cells in larger cells of $1^{\circ} \times 1^{\circ}, 1.5^{\circ} \times 1.5^{\circ}, 2^{\circ} \times 2^{\circ}$ and $3^{\circ} \mathrm{x}$ $3^{\circ}$, and then re-ran all the analyses while including NDVI values from cells of each size. Normalized Difference Vegetation Index data were processed by WinDisp v5.1 software. Geographical transformations were performed by ArcGIS v9.2 software.

Rainfall data for the breeding grounds were obtained from the ERA-Interim project of the Cent re for Medium-Range Weather Forecasts (ECMWF). Cumulated rainfall in March and April for years 1991-2008 was obtained for coordinates $45.0^{\circ} \mathrm{N}$ and $10.5^{\circ} \mathrm{E}$ (the closest point to our study area in the $1.5^{\circ} \times 1.5^{\circ}$ ERA-Interim grid) and related to population indices in each following year. These data were preferred to measures from weather stations in the study area, as ERA-Interim provide a reliable, complete, and consistent series of data over the study period.

The North Atlantic Oscillation (NAO) is a largescale atmospheric oscillation that profoundly affects ecological conditions over vast areas of the northern hemisphere, determining plant leafing, arthropod emergence, arrival, and breeding of birds in northern Europe (Ottersen et al. 2001, Møller 2002, Stenseth et al. 2002). The NAOw is defined as the mean December-February difference in the normalized sea-level pressure between the subtropical center of high surface pressure (Gibraltar) and that of the subarctic center of low surface pressure (southwest Iceland), expressed as the anomaly over the long-term mean (Jones et al. 1997). Positive values are associated with milder and wetter conditions in continental Europe, but drier than average conditions over southern Europe and the Mediterranean area. North Atlantic Oscillation data were obtained from the University 
Fig. 1. Population indices of (a) Common House-Martin and (b) Common Swift. Bars represent bootstrapped standard errors.
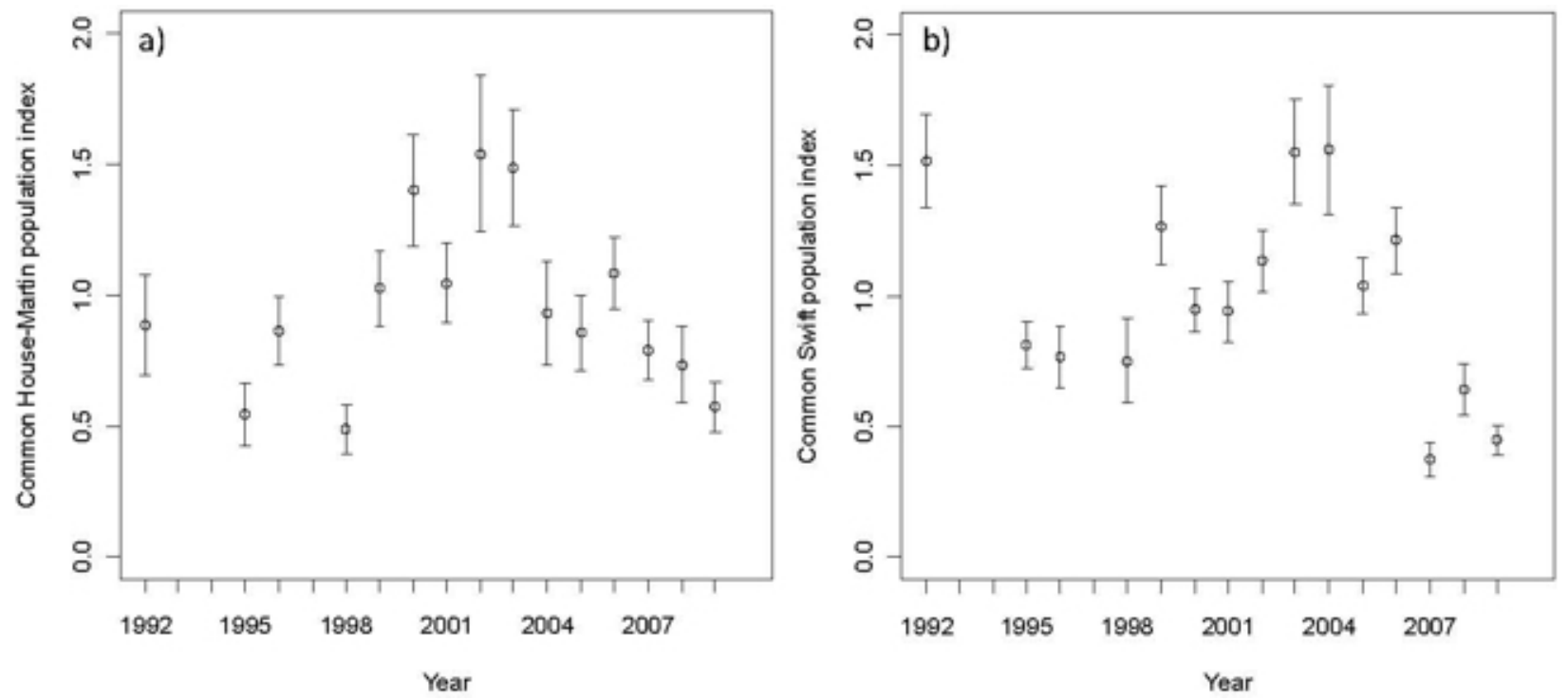

of East Anglia's Climatic Research Unit website (http://www.cru.uea.ac.uk/cru/data/nao/) with updates from http://www.cru.uea.ac.uk/ timo/datapages/ naoi.htm.

\section{Statistical Methods}

The method we used to identify putative wintering areas of our Common House-Martin and Common Swift populations, and simultaneously assess the potential effect of environmental conditions in breeding and wintering grounds, was structured into two main steps.

First, for each square, we regressed the mean annual population index on the NDVI value of that square and on all the other ecological indices that did not depend on the particular square under scrutiny, namely the NAOw index and rainfall in the breeding grounds in the previous year. The linear and the squared term of year, indicated as the number of years elapsed since 1992, were also entered in these models to account for possible nonlinear population trends attributed to causes not accounted for by the ecological variables considered in the present study. Regression models were weighted for the reciprocal of the standard error of population index in each year, to account for differences in the estimate accuracy of the index among years. Putative wintering areas of our martin and swift populations were identified as the cells, within the whole wintering range of these species, where the $t$-values of the NDVI in the regression models were larger than an arbitrarily chosen threshold of +3 , which corresponds to a strong positive relationship among variables. Indeed, according to the formulas in Nakagawa and Cuthill (2007) a $t$-value of +3 in a multiple regression with nine residual degrees of freedom, as in our analyses, corresponds to a partial correlation coefficient of +0.73 among the variables. A positive threshold was chosen as we hypothesized that a high NDVI should promote winter survival and, therefore, be related to a high population index. Moreover, $t$-values were preferred to partial correlation coefficient as they are usually reported in the output of regression analyses.

Once we identified the most probable wintering areas of our martin and swift populations, we calculated the mean within-year NDVI value in the selected cells and entered them in linear regression models with the NAOw index, rainfall in the breeding grounds during the previous spring, and the linear and the squared term of year. We then used an information theory-based approach, which is considered more appropriate than stepwise 
procedures based on $P$ values, to select ecological models that are well-supported by the data (Burnham and Anderson 2002). We first fitted regression models with all possible combinations of the predictors, ranked models according to the values of their Akaike's information criterion corrected for small sample size (AIC ; Hurvich and Tsai 1989), and calculated the difference in $\mathrm{AIC}_{\mathrm{c}}$ $\left(\Delta \mathrm{AIC}_{\mathrm{c}}\right)$ between each models and the model that had the lowest $\mathrm{AIC}_{\mathrm{c}}$. All models whose $\Delta \mathrm{AIC}_{\mathrm{c}}$ was lower than two were considered to have identical support from the data as the best model and constituted the set of candidate models for each species. We then calculated the Akaike weight of each model, and used them to perform Bayesian model averaging (BMA) of the coefficients of the predictors included in the set of candidate models, to obtain parameter estimates that account for the uncertainty in the selection of the model (Burnham and Anderson 2002, Wintle et al. 2003).

All the models included in the final set of models from the BMA were checked for residual temporal autocorrelation by means of autocorrelation functions (ACFs). No analysis suggests a potential temporal structure in the residuals (details not shown). Results from the BMA did not assess the proportion of variance explained by each predictor in the averaged models. For example, when only one model is included in the set of candidate models, the relative importance of all predictors is one, even if large differences exist in the proportions of variance explained by each variable. Therefore, we performed a hierarchical partitioning (HP) analysis to evaluate the independent contribution of each predictor to population indices. Hierarchical partitioning averages the differences in the $R^{2}$ values among all combinations of models with and without a given covariate, and returns the independent contribution of each variable to the variance of the dependent variable (Chevan and Sutherland 1991, Mac Nally and Walsh 2004). However, this procedure does not produce regression coefficients, nor does it identify a set of models that explains the observed variation in the dependent variables. In any case, the BMA and HP should yield similar results, as the variables that contribute less to explain the variance in the observed data should also be considered less important than the others in the BMA.

Given that we could not a priori identify a proper spatial scale for the analyses of NDVI data, we reran all the analyses with the same procedure based on NDVI data averaged in cells of different sizes, from $0.5^{\circ}$ latitude $\mathrm{x} 0.5^{\circ}$ longitude to $3^{\circ}$ latitude $\mathrm{x}$ $3^{\circ}$ longitude.

All statistical analyses were performed using $\mathrm{R}$ 2.8.1 (R Development Core Team 2008), with the MuMIn library (Barton 2010) for the BMA and the hier.part library (Walsh et al. 2003) for the HP analyses.

\section{RESULTS}

Variation in the NDVI in different African areas was included in all candidate models of year-to-year variation in population indices of Common HouseMartin and Common Swift breeding in northern Italy. Importantly, this result was consistently obtained with NDVI values at different spatial scales (Table 1). In particular, variation in population indices of Common House-Martin is consistently positively related to NDVI data in north-western Guinea, Sierra Leone, and Liberia and in some areas of northern Ivory Coast, Togo, Benin, and central Nigeria (Fig. 2). Other small areas in Sudan, Democratic Republic of the Congo, South Africa, and Mozambique could be identified only in the analyses at $0.5^{\circ} \times 0.5^{\circ}$ and $1^{\circ} \times 1^{\circ}$ spatial scales, but not in those including mean NDVI data at larger spatial scales.

Normalized Difference Vegetation Index values in southern Ghana were consistently positively related to Common Swift population indices at all spatial scales, whereas areas in the Democratic Republic of the Congo, Liberia, and Gabon appeared only in the analyses at small spatial scales (Fig. 2).

When we calculated mean within-year NDVI values in the selected cells and entered them in linear regression models together with the other predictors, we found that the NDVI in the putative wintering areas, the linear and squared term of year, and rainfall in the breeding grounds during March and April of the previous year were consistently selected as predictors in the best models of the Common House-Martin in all the analyses that included NDVI data at different spatial scales (Table 1). No other model could be selected according to its $\triangle \mathrm{AIC}_{\mathrm{c}}$ value, and the NAOw index was not included in any model of the set. The NDVI positively predicted Common House-Martin population indices, and the same held true for rainfall in the breeding grounds during March and 
Table 1. Regression models of Common House-Martin and Common Swift population indices obtained by Bayesian model averaging.

\begin{tabular}{|c|c|c|c|c|c|c|c|c|c|c|}
\hline \multirow{2}{*}{$\begin{array}{l}\text { NDVI spatial scale } \\
\text { Variable }\end{array}$} & \multicolumn{2}{|c|}{$0.5^{\circ} \times 0.5^{\circ}$} & \multicolumn{2}{|l|}{$1^{\circ} \times 1^{\circ}$} & \multicolumn{2}{|c|}{$1.5^{\circ} \times 1.5^{\circ}$} & \multicolumn{2}{|l|}{$2^{\circ} \times 2^{\circ}$} & \multicolumn{2}{|l|}{$3^{\circ} \times 3^{\circ}$} \\
\hline & Coef. \pm SE & $(I)$ & Coef. \pm SE & $(I)$ & Coef. \pm SE & $(I)$ & Coef. \pm SE & $(I)$ & Coef. \pm SE & $(I)$ \\
\hline \multicolumn{11}{|l|}{ Common House-Martin } \\
\hline Intercept & $-1.754 \pm 0.279$ & & $-1.888 \pm 0.315$ & & $-1.755 \pm 0.329$ & & $-1.847 \pm 0.347$ & & $-2.137 \pm 0.347$ & \\
\hline Year & $0.077 \pm 0.020$ & $(0.090)$ & $0.076 \pm 0.021$ & $(0.088)$ & $0.076 \pm 0.023$ & $(0.087)$ & $0.071 \pm 0.023$ & $(0.085)$ & $0.073 \pm 0.021$ & $(0.081)$ \\
\hline Year $2^{\dagger}$ & $-5.555 \pm 0.998$ & $(0.146)$ & $-5.447 \pm 1.049$ & $(0.140)$ & $-5.444 \pm 1.144$ & $(0.140)$ & $-5.249 \pm 1.159$ & $(0.137)$ & $-4.978 \pm 1.049$ & $(0.120)$ \\
\hline NDVI & $5.225 \pm 0.811$ & $(0.258)$ & $5.537 \pm 0.910$ & $(0.258)$ & $5.377 \pm 0.989$ & $(0.269)$ & $5.752 \pm 1.065$ & $(0.240)$ & $6.347 \pm 1.021$ & $(0.258)$ \\
\hline Rainfall $(\mathrm{mm})^{\dagger}$ & $2.036 \pm 0.258$ & $(0.449)$ & $2.052 \pm 0.270$ & $(0.451)$ & $1.948 \pm 0.297$ & $(0.430)$ & $2.078 \pm 0.295$ & $(0.461)$ & $2.163 \pm 0.264$ & $(0.477)$ \\
\hline NAOw & $\mathrm{n} / \mathrm{i}$ & $(0.006)$ & $\mathrm{n} / \mathrm{i}$ & $(0.006)$ & $\mathrm{n} / \mathrm{i}$ & $(0.008)$ & $\mathrm{n} / \mathrm{i}$ & $(0.006)$ & $\mathrm{n} / \mathrm{i}$ & $(0.005)$ \\
\hline Cum. AIC ${ }^{\mathrm{c}}$ weight $(n)$ & $0.928(1)$ & & $0.920(1)$ & & $0.857(1)$ & & $0.846(1)$ & & $0.921(1)$ & \\
\hline \multicolumn{11}{|l|}{ Common Swift } \\
\hline Intercept & $-1.780 \pm 0.624$ & & $-1.600 \pm 0.645$ & & $-2.360 \pm 0.776$ & & $-1.140 \pm 0.608$ & & $-1.240 \pm 0.767$ & \\
\hline Year & $-0.022 \pm 0.031$ & $(0.116)$ & $-0.020 \pm 0.030$ & $(0.113)$ & $-0.025 \pm 0.031$ & $(0.105)$ & $-0.041 \pm 0.040$ & $(0.123)$ & $-0.014 \pm 0.023$ & $(0.105)$ \\
\hline Year $2^{\dagger}$ & $-2.410 \pm 1.600$ & $(0.159)$ & $-2.620 \pm 1.570$ & $(0.161)$ & $-1.800 \pm 1.540$ & $(0.142)$ & $-1.710 \pm 1.870$ & $(0.145)$ & $-2.370 \pm 1.340$ & (0.138) \\
\hline NDVI & $6.070 \pm 1.390$ & $(0.348)$ & $5.960 \pm 1.350$ & $(0.303)$ & $7.410 \pm 1.750$ & $(0.337)$ & $6.400 \pm 1.860$ & $(0.227)$ & $6.470 \pm 2.110$ & $(0.229)$ \\
\hline Rainfall $(\mathrm{mm})^{\dagger}$ & $1.660 \pm 0.475$ & $(0.107)$ & $1.600 \pm 0.575$ & $(0.098)$ & $1.740 \pm 0.624$ & $(0.111)$ & $1.690 \pm 0.709$ & $(0.111)$ & $0.975 \pm 0.883$ & $(0.095)$ \\
\hline NAOw & $\mathrm{n} / \mathrm{i}$ & $(0.012)$ & $\mathrm{n} / \mathrm{i}$ & $(0.011)$ & $\mathrm{n} / \mathrm{i}$ & $(0.010)$ & $\mathrm{n} / \mathrm{i}$ & $(0.022)$ & $\mathrm{n} / \mathrm{i}$ & $(0.027)$ \\
\hline Cum. AIC ${ }^{\mathrm{c}}$ weight $(n)$ & \multicolumn{2}{|c|}{$0.811(2)$} & \multicolumn{2}{|c|}{$0.740(2)$} & \multicolumn{2}{|c|}{$0.827(2)$} & \multicolumn{2}{|c|}{$0.651(2)$} & \multicolumn{2}{|c|}{$0.642(3)$} \\
\hline
\end{tabular}

Notes: The NDVI is the within-year mean NDVI value in the putative wintering areas of each species identified using NDVI data aggregated at different spatial scales, and represented in Fig. 2 and Fig. 3. The cumulative AIC ${ }^{\mathrm{c}}$ weight and the number of averaged models $(n)$ from the model averaging procedure are reported below each model. SE is the standard error of the only regression model selected for the Common House-Martin at all spatial scales, and the unconditional standard errors of the coefficients from the model averaging for the Common Swift. $I$ is the proportion of the total variance explained by the independent contribution of each variable, as assessed from the hierarchical partitioning procedure. A variable that was not included in the best candidate set of models is labelled $\mathrm{n} / \mathrm{i}$. The NAOw was never included in the averaged models.

$\dagger$ Coefficients were multiplied by 1000 .

April of the previous year. The coefficients associated to the linear and the squared term of year indicated that Common House-Martin populations had a reverse U-shaped variation during the study period that was not explained by the variables included in the models.

Hierarchical partitioning of variance gave qualitatively identical results, confirming the low importance of the NAOw index, always explaining
$<1 \%$ of variance in the analyses conducted at each spatial scale (Table 1). Mean NDVI values in the putative wintering areas always explained $>24 \%$ of variance of the Common House-Martin population index, and rainfall in the breeding grounds during the previous spring consistently explained $>40 \%$. Finally, $>20 \%$ of variance was explained by the temporal trend, as indicated by the sum of the independent contributions of the linear and the squared term of year in the HP procedure (Table 1). 
Fig. 2. Areas where NDVI significantly predicted population trends of Common House-Martin based on NDVI data aggregated in cells from $0.5^{\circ}$ latitude $\mathrm{x} 0.5^{\circ}$ longitude to $3^{\circ}$ latitude $\mathrm{x} 3^{\circ}$ longitude.
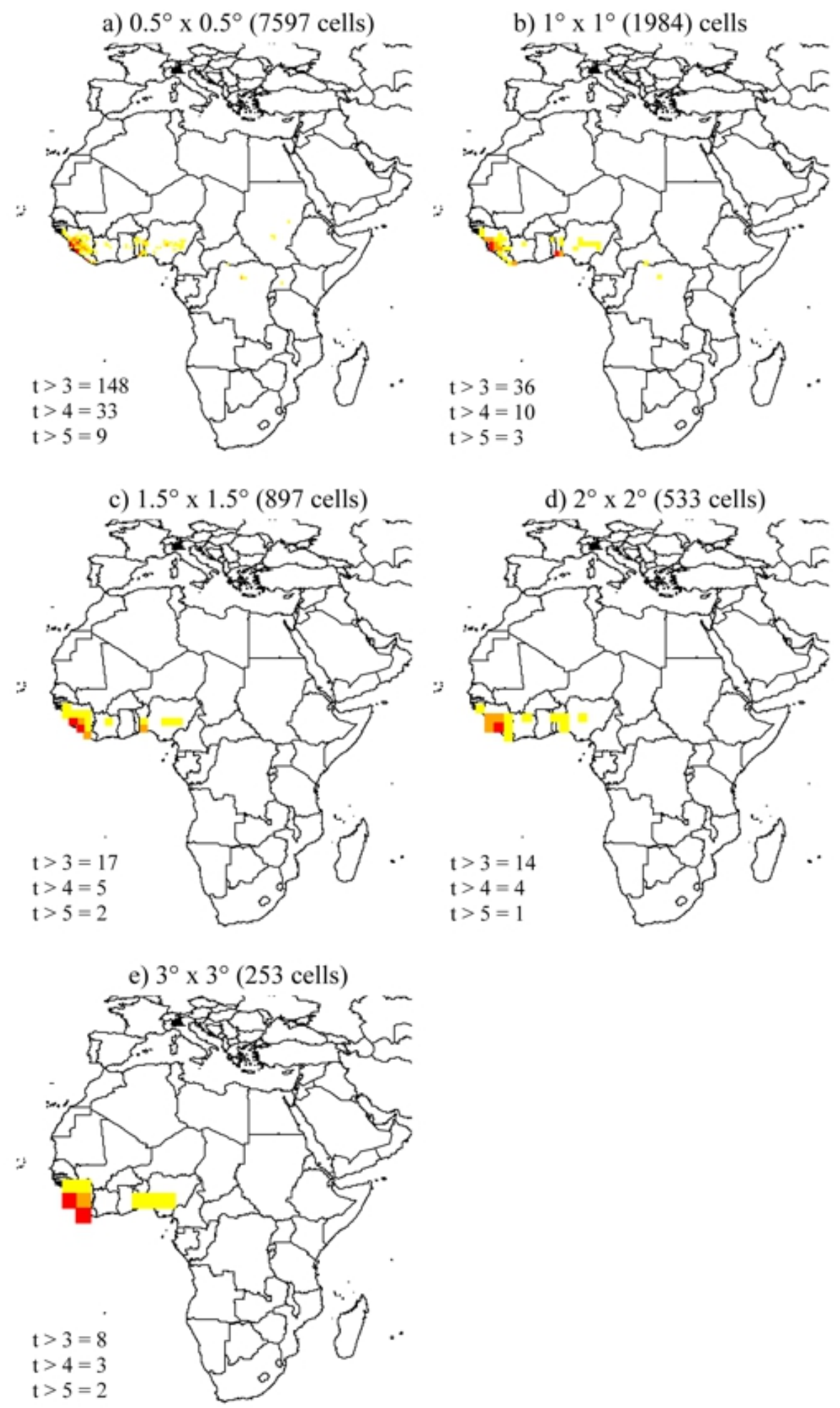

Notes: The size and total number of cells below latitude $20^{\circ} \mathrm{N}$ entered in the analyses is shown, as well as the number of cells at each spatial scale whose $t$-value exceeded 3,4 , or 5 . Yellow cells: $t$-values of NDVI between 3 and 4; orange cells: $t$-values of NDVI between 4 and 5; red cells: $t$-values of NDVI larger than 5. Lombardy is highlighted in black. 
Bayesian model averaging analyses of Common Swift population indices consistently indicated that the best models were those that included alternatively the linear or the squared term of year, in addition to NDVI values and rainfall that were always included. Only in the analysis with NDVI data in $3^{\circ} \times 3^{\circ}$ cells, an additional model including only the NDVI and the squared term of year, had a level of support from the data similar to that of the above-mentioned models and, therefore, was included in the set of the best supported models. In this case, both the NDVI and rainfall were also positively related to Common Swift population indices. The negative coefficients of the linear and the squared term of year suggested that our study population of Common Swift was decreasing at an accelerating rate, probably due to causes not accounted for by the other variables entered in these analyses. The NAOw index was never included in the best supported models (Table 1).

The hierarchical partitioning procedure showed that the NDVI explained a larger proportion of variance $(23 \%-35 \%)$ than rainfall $(10 \%-11 \%)$ in Common Swift population index models, whereas the NAOw only explained $1 \%-3 \%$ of variance. The temporal trend explained $24 \%-27 \%$ of variance in the annual population index, as indicated by the independent contributions of the linear and squared terms of year to the total variance (Table 1).

\section{DISCUSSION}

The area we identified as the wintering grounds of our study populations of Common House-Martin breeding in northern Italy ranges from Guinea to central Nigeria (Fig. 3). Isolated cells in other parts of Africa were selected in the analyses conducted at the lowest spatial scales, but not when we averaged NDVI values over larger areas. Therefore, we conservatively suggest identifying the putative wintering grounds of our population of this species in the area from Guinea to central Nigeria, where NDVI values consistently predicted population indices at all the spatial scales we investigated. The easternmost part of this area overlaps with the westernmost part of the area identified as the putative wintering range of British populations, as assessed by a few recoveries of ringed birds (Wernham et al. 2002, Robinson et al. 2008). This partial spatial segregation of Common HouseMartin breeding in Northern Italy from those breeding in Britain claims to be further confirmed by, e.g., the analysis of stable isotopes of feathers.
If this does not allow for the precise identification of wintering grounds of bird migrating to Africa, it may indicate whether different populations winter in areas with different vegetation (see, e.g., Evans et al. 2003, Møller and Hobson 2003).

The main putative wintering area identified for our population of Common Swift breeding in northern Italy is north of the equator, where this species was not considered to winter until a few years ago (Fig. 2). However, scattered reports of Common Swifts had occurred in western Africa, from Gambia and Liberia, to Nigeria and Cameroon, and northward to Mali (Cramp et al. 2004). In addition, Moreau (1972), based on reports from Ivory Coast, northern Liberia, and southern Nigeria, stated that western Africa must be included in the wintering range of the species. Population dynamics of both species are influenced not only by NDVI variation in the wintering grounds, but also by rainfall in MarchApril of the year preceding each survey. Rainfall in late winter and early spring may influence the availability of flying insects and, therefore, the reproductive success and/or the survival of young which, in turn, affects population consistencies in the following year. In addition, according to HP analyses, the linear and the squared term of year explained a large fraction of variance in both species, thus indicating that other ecological factors not considered in the present study concur in determining the observed decrease in the population indices. However, temporal trends in the population indices differed among species. Coefficients of the Common House-Martin models consistently indicated a reversed U-shaped variation in the population index, with a peak in 1999. The linear and the squared term of year were alternatively selected in the best supported models of the Common Swift, but regression coefficients of these variables were always negative. This indicates that either the population decreased linearly in the study period, after controlling for the effects of the other ecological variables, or declined at an accelerating rate. Coefficients from the averaged models confirmed that this is indeed the case, and that the Common Swift population we studied has been declining at an accelerating rate since 1992.

These results suggest that, at least for some migrant aerial insectivores such as the Common HouseMartin and the Common Swift, winter survival is not the only major determinant of population dynamics. Rainfall in the breeding grounds, which may influence reproductive success, was consistently selected as a predictor of population 
Fig. 3. Areas where NDVI significantly predicted population trends of Common Swift based on NDVI data aggregated in cells from $0.5^{\circ}$ latitude $\mathrm{x} 0.5^{\circ}$ longitude to $3^{\circ}$ latitude $\mathrm{x} 3^{\circ}$ longitude.
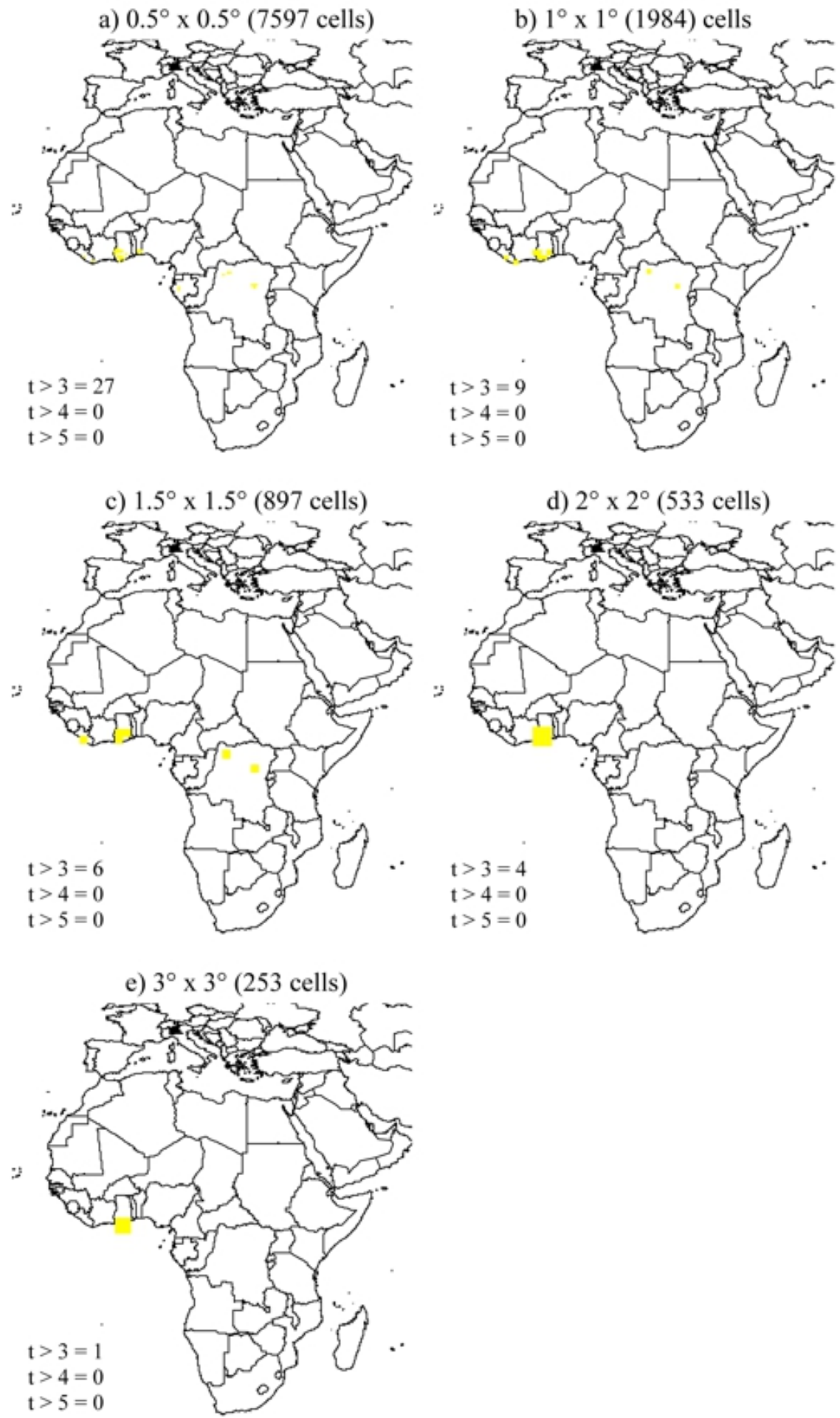

Notes: The size and the total number of cells below latitude $20^{\circ} \mathrm{N}$ entered in the analyses is shown, as well as the number of cells at each spatial scale whose $t$-value exceeded 3,4 , or 5 . Yellow cells: $t$-values of NDVI between 3 and 4 . No cell had a $t$-value larger than 4. Lombardy is highlighted in black. 
indices. However, this does not contradict the results from previous studies on the same species (Robinson et al. 2008) or other Hirundines (Szép and Møller 2005, Szèp at al. 2006) as these studies considered only adult survival, which may be primarily determined by the conditions in the wintering grounds. Conversely, by taking into account population indices (data about the survival of individual birds were unavailable to us), our study had to assess the relative importance of ecological conditions not only in the wintering grounds, which affect adult survival, but also in the breeding grounds, which affect birth and/or young survival rate. Admittedly, we could have included several other ecological, climatic, and/or environmental indices in our models, but we preferred to restrict our investigation to a few predictors, to account for general ecological conditions, and to avoid model overfitting.

Despite the fact that both our species belong to the same guild of aerial insectivores, large differences in the amount of variance explained by the ecological conditions during different periods of the annual life cycle appeared from the HP analyses. Indeed, rainfall in the breeding grounds explained $>40 \%$ of variance in the Common House-Martin population index, whereas the NDVI in the wintering grounds explained about $25 \%$ of variance. Conversely, the NDVI in the wintering grounds explained $23 \%-35 \%$ of variance in the population indices of Common Swift, whereas rainfall in the breeding grounds explained only about $10 \%$. These differences can probably be attributed to differences in the life-history traits of these species. The Common House-Martin has a much shorter lifespan compared with the Common Swift (annual survival rates: Common House-Martin $=0.37 \pm 0.07$, Common Swift $=0.76 \pm 0.03$; Dobson 1990) and has a higher birth rate (typically two clutches of 45 eggs for the Common House-Martin, one clutch of 2-4 eggs for the Common Swift; Cramp 1985, 1988). Therefore, Common House-Martin populations may vary more than those of Common Swift in response to the variation in environmental conditions affecting birth rate.

From a methodological point of view, the method we proposed is an enhancement of that proposed by Szép and Møller (2005) and Szép et al. (2006), in that it simultaneously accounts for the influence of ecological conditions on both the breeding and the wintering grounds on population dynamics. On the one hand, this is imposed by the use of population indices rather than estimates of survival rate of ringed individuals. On the other hand, it opens the possibility of applying this method to a much larger number of species and populations, as data on population variation may be more easily available from monitoring studies than those on survival rates of ringed individuals.

Normalized Difference Vegetation Index values showed a strong spatial autocorrelation, which may have inflated the number of cells selected as putative wintering areas of the Common House-Martins and Common Swifts breeding in northern Italy. However, we are confident that our analyses were weakly affected by this potential source of bias, as analyses run at different spatial scales consistently indicated the same geographical areas as the most probable wintering ranges of our populations (Fig. 2 and Fig. 3). Moreover, regression models should not be biased by spatial autocorrelation in the NDVI values. Indeed, the NDVI values in a given square were entered as independent variables in the regression models of population indices, and regressions were performed one square at time. Similarly, final regression models should be insensitive to spatial autocorrelation in NDVI values, as we entered the mean annual NDVI value in the putative wintering areas into the models. In addition, final averaged regression models based on NDVI data at different spatial scales consistently includes the same predictors, thus indicating that the final models are rather insensitive to the spatial scale at which NDVI data are organized.

Finally, we stress that the identification of the wintering grounds of a population by this procedure must be validated with independent studies based on other methods, such as ring recoveries, that are, however, currently unavailable for our populations. Hence, the maps of the wintering grounds reported here must be considered as tentative. Nonetheless, at the least, these models provide information on the relative influence of ecological conditions at the breeding and at the wintering grounds on population dynamics. In addition, the approach we used is currently the only one available to identify wintering grounds for species, as the Common House-Martin and the Common Swift, where the recoveries of ringed individuals are almost fragmentary, and the application of novel technologies, such as light-level geolocators that in the future may allow tracking small sized birds during their entire life cycle (Stuchbury et al. 2009, Bachler et al. 2010), is still in its infancy. 
Responses to this article can be read online at:

http://www.ace-eco.org/vol6/iss1/art3/responses/

\section{Acknowledgments:}

We thank the Lombardy Regional AdministrationDirezione Generale Agricoltura, Unità Organizzativa Multifunzionalità e Sostenibilità del Territorio, which funded data collection. Comments by Professor Marc-André Villard, Dr. Diego Rubolini and two anonymous referees greatly improved the quality of the paper.

\section{LITERATURE CITED}

Ambrosini, R., A. P. Møller, and N. Saino. 2009. A quantitative measure of migratory connectivity. Journal of Theoretical Biology 257:203-211. doi:1 0.1016/j.jtbi.2008.11.019

Bachler, E., S. Hahn, M. Schaub, R. Arlettaz, L. Jenni, J. W. Fox, V. Afanasyev, and F. Liechti. 2010. Year-round tracking of small trans-Saharan migrants using light-level geolocators. PlosOne 5:4. doi:10.1371/journal.pone.0009566

Balbontin, J., A. P. Møller, I. G. Hermosell, A. Marzal, M. Reviriego, and F. de Lope. 2009. Individual responses in spring arrival date to ecological conditions during winter and migration in a migratory bird. Journal of Animal Ecology 78:981-989. doi:10.1111/j.1365-2656.2009.01573. $\underline{\mathrm{X}}$

Bani, L., D. Massimino, V. Orioli, L. Bottoni, and R. Massa. 2009. Assessment of population trends of common breeding birds in Lombardy, northern Italy, 1992-2007. Ethology, Ecology and Evolution 21:27-44. doi:10.1080/08927014.2009.9522509

Barton, K. 2010. The MuMIN package: multimodel inference. Nordic Network for MultiModal Interfaces (MuMIN), Njalsgade, Denmark. [online] URL: http://cran.r-project.org/web/packages/MuMIn/ index.html (accessed November 2010).

Blondel, J., C. Ferry, and B. Frochot. 1981. Points counts with unlimited distance. Studies in Avian Biology 6:414-420.
Burnham, K. P., and D. R. Anderson. 2002. Model selection and multi-model inference: a practical information-theoretic approach. Second edition. Springer, New York, New York, USA.

Calvert, A. M., S. J. Walde, and P. D. Taylor. $2009 a$ Nonbreeding-season drivers of population dynamics in seasonal migrants: conservation parallels across taxa. Avian Conservation and Ecology 4(2): 5. [online] URL: http://www.ace-eco.org/vol4/iss2/art5/

Calvert, A. M., P. D. Taylor, and S. Walde. $2009 b$. Cross-scale environmental influences on migratory stopover behaviour. Global Change Biology 15:744-759. doi:10.1111/j.1365-2486.2008.01733. $\underline{\mathrm{X}}$

Chantler P. 1999 Family Apodidae (Swifts). Pages 388-457 in J. del Hoyo, A. Elliott, and J. Sargatal, editors. Handbook of the birds of the world. Volume 5: barn-owls to hummingbirds. Lynx Edicions, Barcelona, Spain.

Chevan, A., and M. Sutherland. 1991. Hierarchical partitioning. American Statistician 45: 90-96. doi: $\underline{10.2307 / 2684366}$

Cramp, S., editor. 1985. The birds of the western Palearctic, Volume IV. Oxford University Press, Oxford, UK.

Cramp, S., editor. 1988. The birds of the western Palearctic, Volume V. Oxford University Press, Oxford, UK.

Cramp, S., K. E. L. Simmons, D. W. Snow, and C. M. Perrins. 2004. The birds of the western Palearctic; interactive. BirdGuides, Sheffield, UK.

Dobson, A. 1990. Survival rates and their relationship to life-history traits in some common British birds. Pages 115-146 in D. M. Power, editor. Current ornithology, Volume 7. Plenum Press, New York, New York, USA.

Evans, K. L., S. Waldron, and R. B. Bradbury. 2003. Segregation in the African wintering ranges of English and Swiss Swallow Hirundo rustica populations: a stable isotope study. Bird Study 50:294-299. doi:10.1080/00063650309461322

Fornasari, L., L. Bani, E. de Carli, and R. Massa. 1998. Optimum design in monitoring common birds 
and their habitat. Gibier Faune Sauvage Game and Wildlife Special number, Part 2, 15:309-322.

Frampton, G. K., P. J. van den Brink, and P. J. L. Gould. 2000. Effects of spring drought and irrigation on farmland arthropods in southern Britain. Journal of Applied Ecology 37:865-883. doi:10.1046/j.1365-2664.2000.00541.x

Giralt, D., and F. Valera. 2007. Population trends and spatial synchrony in peripheral populations of the endangered Lesser Grey Shrike in response to environmental change. Biodiversity and Conservation 16:841-856. doi:10.1007/s10531-006-9090-1

Gordo, O., L. Brotons, X. Ferrer, and P. Comas. 2005. Do changes in climate patterns in wintering areas affect the timing of the spring arrival of transSaharan migrant birds? Global Change Biology 11:12-21. doi:10.1111/j.1365-2486.2004.00875.x

Gordo, O., J. J. Sanz, and J. M. Lobo. 2007. Environmental and geographical constraints on common swift and barn swallow spring arrival patterns throughout the Iberian Peninsula. Journal of Biogeography 34:1065-1076. doi:10.1111/j.136 5-2699.2006.01679.x

Gordo, O., and J. J. Sanz. 2008. The relative importance of conditions in wintering and passage areas on spring arrival dates: the case of longdistance Iberian migrants. Journal of Ornithology 149:199-210. doi:10.1007/s10336-007-0260-Z

Hobson, K. A., and L. I. Wassenaar, editors. 2008. Tracking animal migration using stable isotopes. Academic Press, London, UK.

Hurvich, C. M., and C. L. Tsai. 1989. Regression and time-series model selection in small sample sizes. Biometrica 76:297-307. doi:10.1093/biomet $\underline{176.2 .297}$

Jones, P. D., T. Jónsson, and D. Wheeler. 1997. Extension to the North Atlantic Oscillation using early instrumental pressure observations from Gibraltar and southwest Iceland. International Journal of Climatology 17:1433-1450. doi:10.1002 /(SICI)1097-0088(19971115)17:13<1433::AIDJOC203>3.0.CO;2-P

Larson, K. W., and K. A. Hobson. 2009. Assignment to breeding and wintering grounds using stable isotopes: a comment on lessons learned by Rocque et al. Journal of Ornithology 150:709-712. doi:10. 1007/s10336-009-0408-0

Marra, P. P., K. A. Hobson and R. T. Holmes. 1998. Linking winter and summer events in a migratory bird by using stable-carbon isotopes. Science 282:1884-1886. doi:10.1126/science.282.5395.1884

Marra, P.P., and R. T. Holmes. 2001. Consequences of dominance-mediated habitat segregation in American Redstarts during the nonbreeding season. Auk 107:96-106.

Massimino, D., V. Orioli, R. Massa, and L. Bani. 2008. Population trend assessment on a large spatial scale: integrating data collected with heterogeneous sampling schemes by means of habitat modeling. Ethology, Ecology and Evolution 20:141-153. doi: $\underline{10.1080 / 08927014.2008 .9522534}$

Mac Nally, R., and C. J. Walsh. 2004. Hierarchical partitioning public-domain software. Biodiversity and Conservation 13: 659-660. doi:10.1023/B:BIO C.0000009515.11717.0b

Møller, A. P. 2002. North Atlantic Oscillation (NAO) effects of climate on the relative importance of first and second clutches in a migratory passerine bird. Journal of Animal Ecology 71:201-210. doi:1 $\underline{0.1046 / j .1365-2656.2002 .00589 . x}$

Møller, A. P., and K. A. Hobson. 2003. Heterogeneity in stable isotopes profiles predicts coexistence of populations of barn swallows Hirundo rustica differing in morphology and reproductive performance. Proceedings of the Royal Society of London Series B-Biological Sciences 71:1355-1362.

Moreau, R. E. 1972. The Palearctic-African bird migration systems. Academic Press, London, UK.

Nebel, S., A. Millis, J. D. McCracken, and P.D. Taylor. 2010. Declines of aerial insectivores in North America follow a geographic gradient. Avian Conservation and Ecology 5(2): 1. [online] URL: : http://www.ace-eco.org/vol5/iss2/art1/

Nakagawa, S., and I. C. Cuthill. 2007. Effect size, confidence interval and statistical significance: a practical guide for biologists. Biological Reviews 82:591-605. doi:10.1111/j.1469-185X.2007.00027. $\underline{\mathrm{X}}$ 
Newton, I. 2004. Population limitation in migrants. Ibis 146:197-226. doi:10.1111/j.1474-919X.2004.0 0293.x

Ottersen, G., B. Planque, A. Belgrano, E. Post, P. C. Reid, and N.C. Stenseth. 2001. Ecological effects of the North Atlantic Oscillation. Oecologia 128:114. doi:10.1007/s004420100655

R Development Core Team. 2008. $R$ : a language and environment for statistical computing. $\mathrm{R}$ Foundation for Statistical Computing, Vienna, Austria. [online] URL: http://www.R-project.org.

Robinson, R. A., D. E. Ballmer, and J. H. Marchant. 2008. Survival rates of hirundines in relation to British and African rainfall. Ringing and Migration 24:1-6.

Saino, N., T. Szép, R. Ambrosini, M. Romano, and A. P. Møller. 2004. Ecological conditions during winter affect sexual selection and breeding in a migratory bird. Proceedings of the Royal Society of London Series B-Biological Sciences 271:681-686. doi:10.1098/rspb.2003.2656

Sanderson, F. J., P. F. Donald, D. J. Pain, I. J. Burfield, and F. P. J. van Bommel. 2006. Long-term population declines in Afro-Palearctic migrant birds. Biological Conservation 131:93-105. doi:10 .1016/j.biocon.2006.02.008

Sillett, T. S., and R. T. Holmes. 2002. Variation in survivorship of a migratory songbird throughout its annual cycle. Journal of Animal Ecology 71:296308. doi:10.1046/j.1365-2656.2002.00599.x

Smith, R. J., and F. R. Moore. 2005. Fat stores of American redstarts Setophaga ruticilla arriving at northerly breeding grounds. Journal of Avian Biology 36:117-126. doi:10.1111/j.0908-8857.200 $\underline{\text { 5.03329.x }}$

Stenseth, N. C., A. Mysterud, G. Ottersen, J. W. Hurrell, C. Kung-Sik, and M. Lima. 2002. Ecological effects of climate fluctuations. Science 297:1292-1296. doi:10.1126/science.1071281

Spina, F., and S. Volponi. 2008a. Atlante della migrazione degli uccelli in Italia. Volume 1: nonPasseriformi. ISPRA-MATTM, Rome, Italy.

Spina, F., and S. Volponi. 2008b. Atlante della migrazione degli uccelli in Italia. Volume 2: Passeriformi. ISPRA -MATTM, Rome, Italy.
Stokke, B. G., A. P. Møller, B. E. Saether, G. Rheinwald, and H. Gutscher. 2005. Weather in the breeding area and during migration affects the demography of a small long-distance passerine migrant. Auk 122:637-647. doi:10.1642/0004-8038 (2005)122[0637:WITBAA]2.0.CO;2

Stutchbury, B. J. M., S. A. Tarof, T. Done, E. Gow, P. M. Kramer, J. Tautin, J. W. Fox, and V. Afanasyev. 2009. Tracking long-distance songbird migration by using geolocators. Science 323:896. doi:10.1126/science.1166664

Szép, T., and A. P. Møller. 2005. Using remote sensing data to identify migration and wintering areas and to analyze effects of environmental conditions on migratory birds. Pages 390-400 in R. Greenberg, and P. P. Marra, editors. Birds of two worlds: the ecology and evolution of migration. The John Hopkins University Press, Baltimore, Maryland, USA.

Szép, T., A. P. Møller, S. Piper, R. Nuttall, Z. D. Szabo, and P. L. Pap. 2006. Searching for potential wintering and migration areas of a Danish Barn Swallow population in South Africa by correlating NDVI with survival estimates. Journal of Ornithology 147:245-253. doi:10.1007/s10336-006 -0060-x

Szép, T., K. A. Hobson, J. Vallner, S. E. Piper, B. Kovács, D. Z. Szabó, and A. P. Møller. 2009. Comparison of trace element and stable isotope approaches to the study of migratory connectivity: an example using two hirundine species breeding in Europe and wintering in Africa. Journal of Ortnithology 150:621-636. doi:10.1007/s10336-00 9-0382-6

Tucker, C., J. Pinzon, M. Brown, D. Slyback, E. Pack, R. Mahoney, E. Vermote, and N. Ell Saleours. 2005. An extended AVHRR 8-km NDVI dataset compatible with MODIS and SPOT vegetation NDVI data. International Journal of Remote Sensing 26:4485-4498. doi:10.1080/014311605001 $\underline{68686}$

Turner A. K. 2004. Family Hirundinidae (swallows and martins). Pages 602-685 in J. del Hoyo, A. Elliott and D. A. Christie, editors. Handbook of the birds of the world. Volume 9: cotingas to pipits and wagtails. Lynx Edicions, Barcelona, Spain. 
Walsh, C., R. Mac Nally, M. Walsh, and G. License. 2003. The hierarchical partitioning package: hierarchical partitioning. [online] URL: http://cran. r-project.org/web/packages/hier.parthttp://cran.r-project. org/web/packages/hier.part. Accessed November 2010.

Webster, M. S., P. P. Marra, S. M. Haig, S. Bensch, and R. T. Holmes. 2002. Links between worlds: unraveling migratory connectivity. Trends in Ecology and Evolution 17:76-83. doi:10.1016/S01 69-5347(01)02380-1

Wernham, C. V., M. P. Toms, J. H. Marchant, J. A. Clark, G. M. Siriwardena, and S. R. Baillie, editors. 2002. The migration atlas: movements of the birds of Britain and Ireland. T. and A. D. Poyser, London, UK.

Wintle, B. A., M. A. McCarthy, C. T. Volinsky, and R. P. Kavanagh. 2003. The use of Bayesian model averaging to better represent uncertainty in ecological models. 17:1579-1590.
Wolda, H. 1978. Seasonal fluctuations in rainfall, food and abundance of tropical insects. Journal of Animal Ecology 47:369-381.

Zink, G. 1975. DerZug europäischer Singvögel: ein Atlas der Wiederfunde beringter Vögel. 2. Vogelwarte Radolfzell am Max-Plank Institute für Verhaltenphysiologie, Schloss Möggingen, Germany. 